\title{
Characterization of Oxide Growth on Surface of Al-Mg-Si Welded Joint
}

\author{
Azman Jalar, ${ }^{1}$ Nur Azida Che Lah, ${ }^{1,2}$ Norinsan Kamil Othman, ${ }^{1}$ Roslinda Shamsudin, \\ Abdul Razak Daud, ${ }^{1}$ and Syed Roslee Sayd Bakar ${ }^{3}$ \\ ${ }^{1}$ School of Applied Physics, Faculty of Science and Technology, Universiti Kebangsaan Malaysia, 43600 Bangi, Selangor, Malaysia \\ ${ }^{2}$ Fabrication \& Joining Section, Universiti Kuala Lumpur Malaysia France Institute, Section 14, Jalan Teras Jernang, \\ 43650 Bandar Baru Bangi, Selangor, Malaysia \\ ${ }^{3}$ Science and Technology Research Institute for Defence (STRIDE), 43000 Kajang, Selangor, Malaysia
}

Correspondence should be addressed to Azman Jalar; azmn@ukm.my

Received 13 May 2013; Revised 3 December 2013; Accepted 5 December 2013; Published 16 February 2014

Academic Editor: Pavel Lejcek

Copyright (c) 2014 Azman Jalar et al. This is an open access article distributed under the Creative Commons Attribution License, which permits unrestricted use, distribution, and reproduction in any medium, provided the original work is properly cited.

\begin{abstract}
Al-Mg-Si (AA6061) Al alloy plates were joined by the method of gas metal arc welding using Al-5Mg (ER5356) filler metal and were subjected to the oxidation test in flowing air environment at $600^{\circ} \mathrm{C}$ from 8 to 40 hours and the weight gain was measured. The characteristic of oxide grown on welded zone surface was examined by SEM/EDS, XRD, and XPS. Oxide was observed to grow on the fused metal surface suggesting the possibility of modifying the oxide chemistry under high temperature environment. It was found that the oxidation behavior of fused metal affected by the nature of their oxide growth and morphology, was influenced by their welding process and the difference in the chemical composition.
\end{abstract}

\section{Introduction}

Aluminium (Al)-Magnesium (Mg)-Silicon ( $\mathrm{Si}$ ) such as AA6061 Al alloys are important in industries as they are used for a wide variety of products and applications from truck bodies and frames to screw machine parts and structural components. It offers a range of good mechanical properties and corrosion resistance, formability, and weldability $[1,2]$. It can be fabricated by most of the commonly used techniques. In addition, the alloys are desirable materials for making components of internal combustion engine such as cylinder block, cylinder head, and piston which are usually subjected to a relatively high temperature applications $[3,4]$.

At present, the effect of oxidation temperature on bare material or unwelded structure of Al-Mg alloy is well established. Meanwhile, when it involved a welded structure, the influence of alloying element from filler metal addition on the growth and morphology of oxide on the fused or welded surface shows a clear difference. Welding an $\mathrm{Al}$ represents a critical operation due to its complexity and the high level of defect that can be produced in the fused metal. The main problems are related to the properties of $\mathrm{Al}$ that is high thermal conductivity, high chemical reactivity with oxygen, and high hydrogen solubility at high temperature $[4,5]$.

In other words, when it involved a welded structure, the oxidation process may be more complex for fused metal parts of alloys with different oxide growth rate due to (i) nature of difference of metallurgical structure from filler and parent metal and (ii) the presence of discontinuities resulting from previous welding procedure [4]. It is not a simple system because slightly different adsorption and surface conditions could lead to significant differences in the resultant reaction. The oxidation kinetics of a metal or alloy was determined by a number of processes which are atomic transport through the oxide layer and reactions at one or both interfaces (metal oxide layer and oxide gas) [5]. The resistance of a metal attack by aggressive gasses is primarily related to the protective properties of the surface oxide layer.

A study by Maggiolino and Schmid [4] showed that at temperatures of more than $500^{\circ} \mathrm{C}$, oxide formed on 6000 series $\mathrm{Al}$ alloy surface has resulted in a very significant weight gain which means more metal loss and degradation 


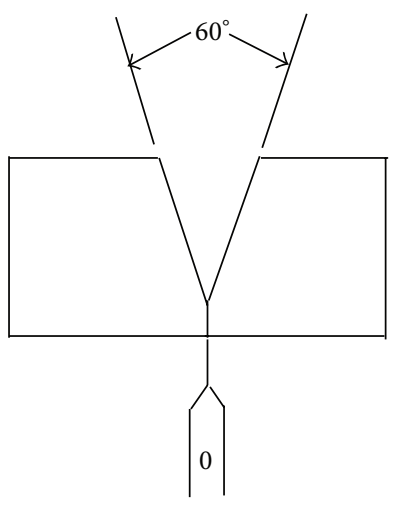

(a)

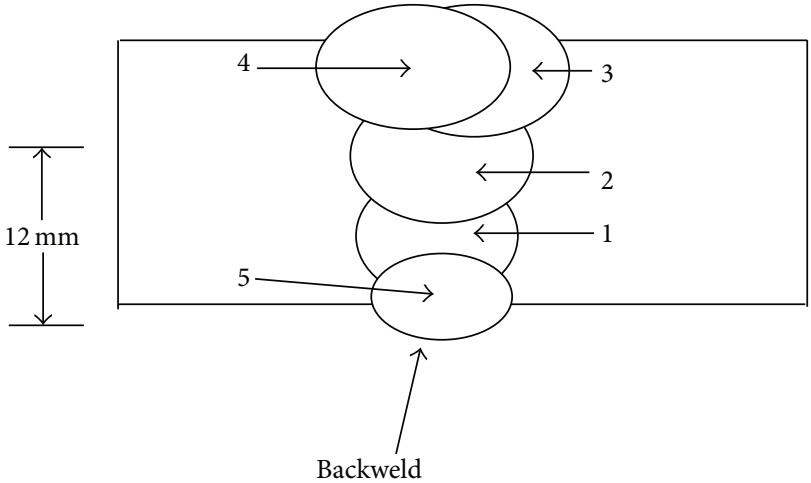

(b)

FIgURE 1: Welding details of AA6061 Al alloy plates: (a) joint configuration and (b) welding sequence, $1 \rightarrow 2 \rightarrow 3 \rightarrow 4 \rightarrow 5$ (backweld).

TABLE 1: Chemical composition in wt\% of base metal AA6061 Al alloy and filler metal ER5356.

\begin{tabular}{lccccccccc}
\hline & $\mathrm{Si}$ & $\mathrm{Fe}$ & $\mathrm{Cu}$ & $\mathrm{Mn}$ & $\mathrm{Mg}$ & $\mathrm{Cr}$ & $\mathrm{Zn}$ & $\mathrm{Ti}$ & $\mathrm{Al}$ \\
\hline AA6061 & 0.8 & 0.7 & 0.4 & 0.15 & 1.2 & 0.35 & 0.25 & 0.15 & 96.10 \\
ER5356 & 0.27 & 0.40 & 0.10 & 0.10 & 5.00 & - & - & - & 94.13 \\
\hline
\end{tabular}

of its mechanical properties [5-7]. Frolish et al. [7] reported that the oxide scale formed on $\mathrm{Al}$ alloys has been more tenacious which led to the intermixing of the surface metal and oxide scale leading to a complex surface and subsurface layer. It is well known that $\mathrm{Mg}$ which is one of the common alloying elements for $\mathrm{Al}$ alloy has high affinity to oxygen and is particularly prone to surface degradation during high temperature manufacturing stages such as welding or heat treatment [8-11]. van Agterveld et al. [1] reported that the Al$\mathrm{Mg}$ alloy exposed up to $400^{\circ} \mathrm{C}$ in an air circulation furnace formed surface oxide layer largely consisting of $\mathrm{MgO}$.

In this present work, a study was conducted on the oxide scale formed on the fused metal part of AA6061 welded joint that was subjected to high temperature oxidation test. The nature of the oxide growth pattern, morphology, and phases was characterized using scanning electron microscope (SEM) equipped with energy dispersive X-ray spectroscopy (EDS) and X-ray diffraction (XRD) technique. In the present investigation, the X-ray photoelectron spectroscopy (XPS) was applied to get more information on the preferential interaction of the formed oxide.

\section{Material and Methods}

Samples used for high temperature oxidation test were AA6061 welded alloy focusing only on the fused metal part prepared by means of gas metal arc welding (GMAW) technique operating at $25 \mathrm{~V}$ and $185 \mathrm{~A}$, using commercially available filler metal ER5356 (Al-5Mg). Table 1 shows the chemical composition of the base and filler metals. The welding parameters used to join AA6061 alloy plate is shown in Table 2. Figure 1 shows the joint configuration and sequence of welding process used in this work.
TABLE 2: Welding parameters used to weld AA6061 Al alloy.

\begin{tabular}{lc}
\hline Welding parameter & Description \\
\hline Diameter filler wire ER5356 & $1.00 \mathrm{~mm}$ \\
Polarity & $\begin{array}{c}\text { Direct current reverse } \\
\text { polarity (DCRP) }\end{array}$ \\
Amperage & $185 \mathrm{~A}$ \\
Voltage & $25 \mathrm{~V}$ \\
Travelling speed & $400 \mathrm{~mm} / \mathrm{min}$ \\
Heat input & $0.75 \pm 0.08 \mathrm{KJ} / \mathrm{mm}$ \\
Shielding gas & Argon \\
\hline
\end{tabular}

The AA6061 Al alloy plates had original dimension of $300 \mathrm{~mm}$ (length) $\times 200 \mathrm{~mm}$ (width) $\times 12 \mathrm{~mm}$ (thick) with single-V groove butt joint. Following the welding procedure, the bead contour, bead appearance, and weld quality have been inspected visually to identify the discontinuities of the fused metal part. Then, samples with dimension of $60 \mathrm{~mm}$ (length) $\times 10 \mathrm{~mm}$ (width) $\times 5 \mathrm{~mm}$ (thick) were cut from the welded plate comprising of base and fused metal parts. The samples were mechanically grinded using silicon carbide papers and followed by polishing with $3 \mu$ and $1 \mu$ diamond paste. These samples were utilized for high temperature oxidation test. The oxidation test was carried out using a laboratory type air circulated horizontal tube furnace at $600^{\circ} \mathrm{C}$ in air atmosphere for the duration of $8,20,30$, and 40 hours followed by a slow cooling rate of $1.5^{\circ} \mathrm{C} \mathrm{min}$. The samples weight before and after oxidation test were determined by using an electronic balance with an accuracy of $\pm 0.001 \mathrm{mg}$.

Although the oxidation test was studied for $600^{\circ} \mathrm{C}$ at all duration exposures which are 8, 20, 30, and 40 hours, the characterization analysis was evaluated only for sample undergone oxidation for 40 hours. The oxidized fused metal samples were then characterized using a scanning electron microscope (SEM) LEO 1450 model equipped with an energy dispersive X-ray spectroscopy (EDS) to obtain oxide scale morphology, cross-sectional images, and the constituent 


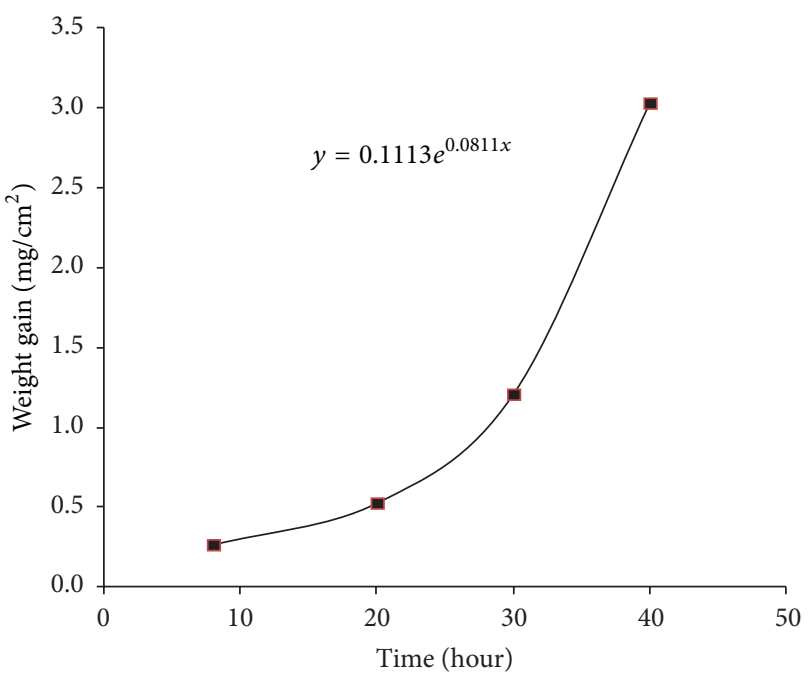

FIGURE 2: Weight gain per unit surface area versus time for welded AA6061 Al alloy sample heated at $600^{\circ} \mathrm{C}$.

element present. Phase identification was carried out using X-ray diffractometer (XRD) Bruker AXS:D8 Advance model.

The evolution of the chemical composition, mainly the depth distribution of various chemical species within the grown oxide scales on fused metal, was studied by using Xray photoelectron spectroscopy (XPS) Axis Ultra model. The spectra were taken with the $\mathrm{Al} \mathrm{K} \alpha \mathrm{X}$-ray source operating at $400 \mathrm{~W}(15 \mathrm{kV}-27 \mathrm{~mA})$. The fused metal samples were analyzed at an electron take-off angle of $70^{\circ}$, measured with respect to the surface plane. XPS spectrum analysis was performed by peak fitting employing the respective procedures using the data system analysis. During data fitting, a Shirley background correction was applied to all spectra. In order to identify the elements present, a high resolution broad scan survey spectrum is obtained.

\section{Results and Discussion}

3.1. Kinetics of Oxidation. The overall weight gain per unit area of AA6061 welded Al alloy, $W$, including both base and fused metal parts due to the formation of oxide was calculated using the following:

$$
\left(\frac{\Delta W}{A}\right)_{\mathrm{WD}}=\frac{W_{f}-W_{i}}{A},
$$

where $\Delta W$ is the overall weight gain of the welded sample (mg), $W_{i}$ and $W_{f}$ represent the sample's weight before and after heating, and $A$ is surface area of the sample $\left(\mathrm{cm}^{2}\right)$.

In this part, the analyses were focused on the samples which exposed to the temperature of $600^{\circ} \mathrm{C}$ at all exposure durations which are $8,20,30$, and 40 hours. At $600^{\circ} \mathrm{C}$, the weight gain of sample due to the formation of oxide increased drastically after heating for more than 30 hours as shown in Figure 2. This statement is in agreement with the optical images in Figure 3 and surface micrograph of oxidized fused metal sample as indicated in Figure 5. The oxide growth rate seems to follow an exponential equation, shown by the following:

$$
\frac{\Delta W}{A}=C e^{k t}
$$

where $\Delta W$ is the overall weight gain (mg), $A$ is surface area $\left(\mathrm{cm}^{2}\right), t$ is exposure time (hours), and $k$ and $C$ are constants $[5,12]$.

3.2. Oxide Scale Characterization. Figure 3 shows the optical and macrostructure images of the AA6061 welded Al alloy before being subjected to oxidation test. Figure 3(b) indicated the macrostructure image of welded joint showing the sequence of weld layers. It shows the presence of imperfection such as pore resulting from previous welding process. It is believed that the formation of porosity is caused by the absorption of gases such as oxygen, or hydrogen in the molten weld pool which is then released during solidification and becomes trapped in the weld metal [4].

Figure 4 shows the welded sample after oxidation process being set at $600^{\circ} \mathrm{C}$ for 40 hours duration. Compared to the nonoxidized sample in Figure 3(a), it shows the color of the welded samples especially in fused metal part turning from the metallic-like appearance to grayish black after exposure at $600^{\circ} \mathrm{C}$ (Figure 4 ) as the impact of oxidation process. From the results, it clearly implies that the oxidation temperature has a strong effect on the appearance and the oxidation behavior.

Figures 5(a) and 5(b) show the SEM images of fused metal part before and after being subjected to oxidation test at $600^{\circ} \mathrm{C}$ for 40 hours. The changes of appearance due to oxidation were supported by the SEM micrograph shown in Figure 5(b) indicating the formation of oxide scale on the sample's surface. It was found that, at $600^{\circ} \mathrm{C}$, the oxidized fused metal surface was found to be distributed by flake-like white grains, eventually proving the color changes from the grayish black oxides to white flake-like oxides surface. The distribution of oxides was uneven. As discussed earlier, the oxidized fused metal surface was covered with agglomerated oxide grains forming a porous structure. This oxides formation supports the experimental result that the grown oxide or weight gain in welded AA6061 Al alloy at $600^{\circ} \mathrm{C}$ increased with time exponentially (Figure 2).

The enrichment of elements was significantly shown in cross-sectional analyses with EDS maps of oxidized and nonoxidized fused metal part in Figures 6 and 7, respectively.

The oxides enrichment that contained $\mathrm{Al}, \mathrm{Mg}, \mathrm{Si}$, and $\mathrm{O}$ was found to be scattered evenly in Figure 6 indicating that the sample was free from oxidation exposure. On the other hand, an enrichment of oxides was found to be distributed unevenly especially at the oxide-alloy interface of oxidized fused metal part as shown in Figure 7. It was found that the outer oxide scale was thick and porous. In the internal part of the sample's substrate, the oxide nodule was formed and the EDS maps analyses confirmed an enrichment of oxides that contained $\mathrm{Mg}$ and Si.

Meanwhile, the XRD scan of oxidized and nonoxidized sample was shown in Figures 8(a) and 8(b). Figure 8(a) shows the unoxidized fused metal surface of AA6061 welded Al 


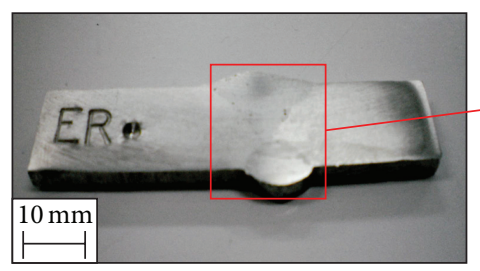

(a)

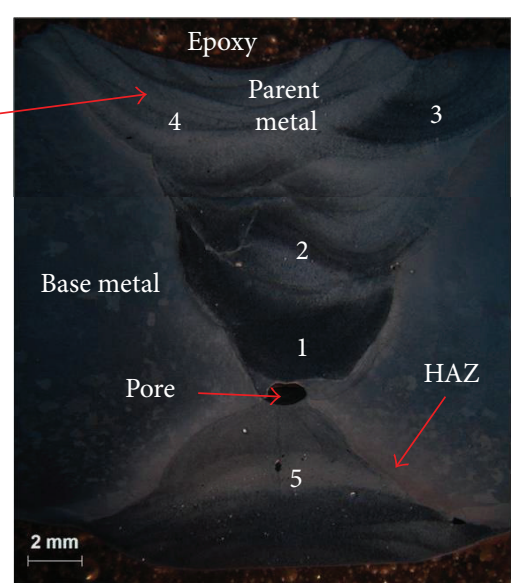

(b)

FIGURE 3: AA6061 welded sample before being subjected to oxidation test consisting of (a) optical image and (b) macrostructure showing parent, fusion metal, and heat affected zone (HAZ).

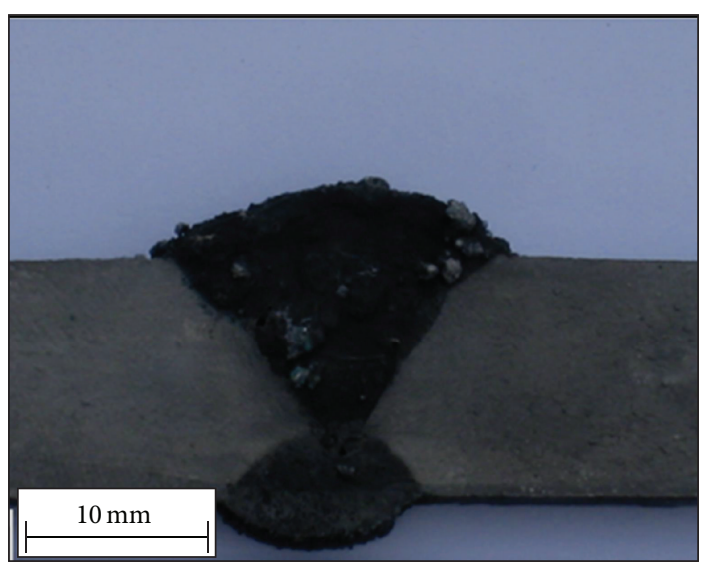

FIgURE 4: Optical image of oxidized AA6061 welded sample consisting of parent and fusion metal for 40 hours at $600^{\circ} \mathrm{C}$.

alloy. The XRD spectrum shows the presence of $\mathrm{Al}$ and $\delta$ $\mathrm{Al}_{2} \mathrm{O}_{3}$. Meanwhile, the XRD scan detected the presence of phases such as $\delta-\mathrm{Al}_{2} \mathrm{O}_{3}, \gamma-\mathrm{Al}_{2} \mathrm{O}_{3}$, and $\mathrm{MgO}$ as shown in Figure $8(\mathrm{~b})$. $\mathrm{MgO}$ phases had been detected with low peaks of intensity and did not exhibit a broadening behavior. The patches of Mg-rich oxides present in the oxidized samples shown by SEM micrographs and EDS maps analyses (Figure 7), possibly from $\mathrm{MgO}$. At $600^{\circ} \mathrm{C}$ the presence of Al-rich oxides is more significant instead of oxides that contained $\mathrm{Mg}$ and $\mathrm{Si}$ due to the presence of $\gamma-\mathrm{Al}_{2} \mathrm{O}_{3}$ and $\delta-\mathrm{Al}_{2} \mathrm{O}_{3}$ (Figure 8). Moreover, it is believed that the presence of $\mathrm{MgO}$ spectrums (Figure 8(b)) was due to a higher diffusion rate of $\mathrm{Mg}^{2+}$ and $\mathrm{Al}^{3+}$ into $\mathrm{MgO}$.

3.3. Chemical State of the Ions. Further analysis of oxide formation on the surface of fused metal part was confirmed by XPS analysis in Figure 9 since the details of oxide formation were not fully justified in XRD scan (Figure 8). The analysis was only carried out for oxidized welded sample at $600^{\circ} \mathrm{C}$ for 40 hours. A wide XPS spectrum shows that the sample contains the species of Si 2 p, Mg 2 p, Al 2 p, C 1 s, and $\mathrm{O} 1 \mathrm{~s}$ which is clearly seen in the survey. High resolution of $\mathrm{O}$ $1 \mathrm{~s}, \mathrm{Mg} 2 \mathrm{p}, \mathrm{Si} 2 \mathrm{p}$, and Al $2 \mathrm{p}$ of the fused metal oxide surface is shown in Figure 10. The XPS survey spectra showed $\mathrm{Al}, \mathrm{Mg}$, $\mathrm{Si}, \mathrm{O}$, and $\mathrm{C}$ to be the main elements with other elements only appearing at trace levels. The graph profile shown is corrected for sample charging effects, where the spectra were shifted to set the $\mathrm{C}$-C component of the $\mathrm{C} 1 \mathrm{~s}$ core level peak at a binding energy of $284.8 \mathrm{eV}$.

It is emphasized in previous literature [10-14] that oxygen molecules approaching the $\mathrm{Al}$ surface have two major possibilities in surface interaction. In that case, either they are dissociated in the vicinity of the surface by a charge transfer into the oxygen antibonding molecular orbital or otherwise the whole oxygen molecule is reflected from the surface [15]. The O $1 \mathrm{~s} \mathrm{BE}$ of $533.03 \pm 0.08 \mathrm{eV}$ for the $\mathrm{O} 1 \mathrm{~s}$ main peak in Figure $10(\mathrm{~d})$ can be compared with the corresponding $\mathrm{O} 1 \mathrm{~s}$ $\mathrm{BE}$ of $531.8 \pm 0.5 \mathrm{eV}$ and $531.2 \pm 0.3 \mathrm{eV}$, as reported for bulk and thin films of $\mathrm{MgO}$ and $\mathrm{MgAl}_{2} \mathrm{O}_{4}$ by Jeurgens et al. [13]. It also corresponds to the formation of $\gamma-\mathrm{Al}_{2} \mathrm{O}_{3}$ and $\mathrm{SiO}_{2} \alpha$ quartz with BE of $533.83 \pm 0.02 \mathrm{eV}$.

In order to measure the various binding energy positions, the graph profile was determined accurately by fitting of a third degree polynomial function through the top of the respective peaks. The two $\mathrm{Al}$ species was observed in Figure 10(a). The Al $2 \mathrm{p}$ binding energy (BE) value of $74.05 \pm$ 0.1 and $72.3 \pm 0.1 \mathrm{eV}$ of the interfacial oxide scale species in (Figure 10(a)) lies in between $72.9 \pm 0.1$ and $74.3 \pm 0.1 \mathrm{eV}$ as reported for thin $\gamma-\mathrm{Al}_{2} \mathrm{O}_{3}$ films and $\mathrm{Al}$ was observed in [13]. It is noted in previous literature that this $\mathrm{BE}$ value (i.e., $74.05 \mathrm{eV}$ ) is slightly higher than the corresponding $\mathrm{Al} 2 \mathrm{p} \mathrm{BE}$ value of $74.0 \pm 0.1 \mathrm{eV}$ as reported by Jeurgens et al. [13] for Al cations. It has been previously reported that the $\mathrm{BE}$ of the $\mathrm{Al} 2 \mathrm{p}$ for $\mathrm{Al}_{2} \mathrm{O}_{3}$ is $74.4-75.8 \mathrm{eV}$ [13]. It is suggested that the interfacial 


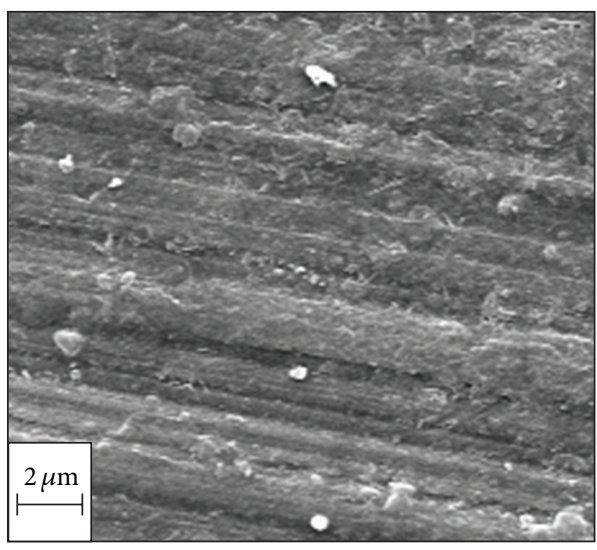

(a)

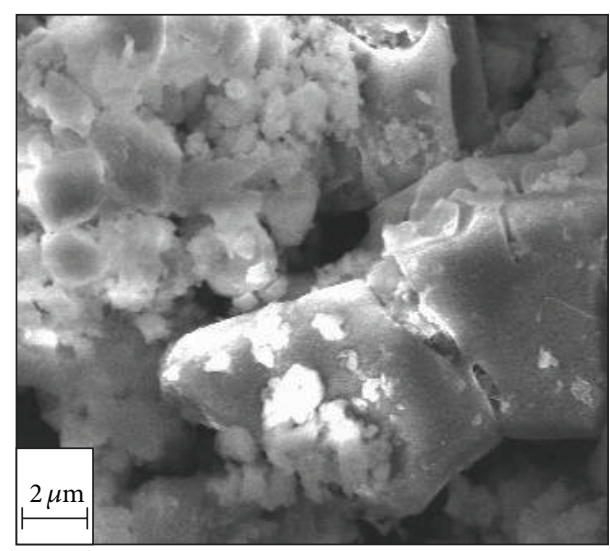

(b)

FIGURE 5: SEM micrograph of fused metal surface oxide morphology, (a) before and (b) after being subjected to oxidation test for 40 hours at $600^{\circ} \mathrm{C}$

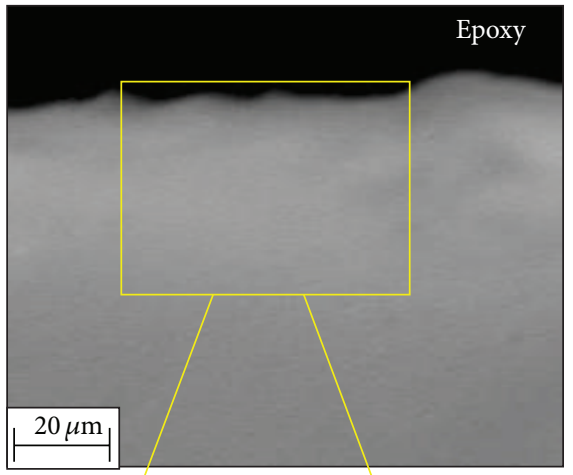

(a)

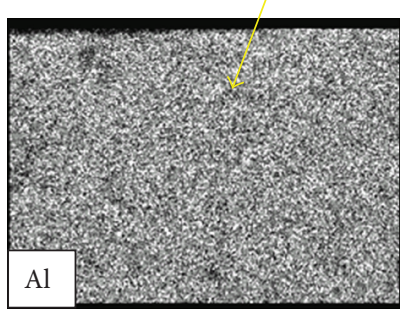

(b)

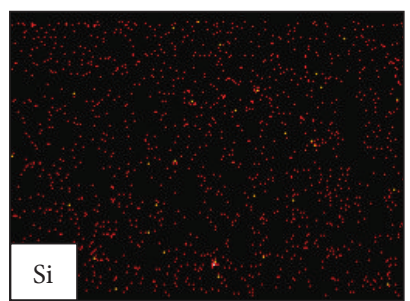

(d)

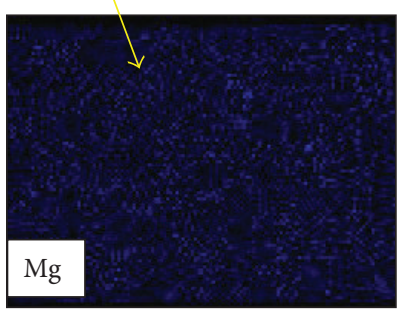

(c)

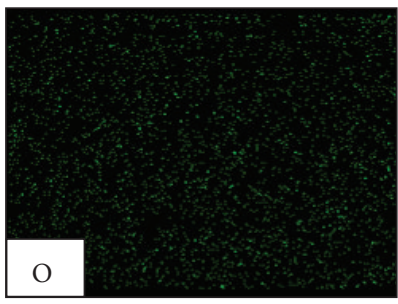

(e)
FIGURE 6: A cross-sectional image of nonoxidized fused metal part of welded AA6061 Al alloy, (a) SEM image, and EDS maps analyses of (b) $\mathrm{Al}$, (c) $\mathrm{Mg}$, (d) Si, and (e) O.
$\mathrm{Al}$ cations that give rise to the $\mathrm{Al} 2 \mathrm{p}$ species in the grown oxide scale, are in their formal oxidation state which is $\mathrm{Al}^{3+}$. Its chemical environment possesses the similarity of those $\mathrm{Al}$ cations in $\mathrm{Al}_{2} \mathrm{O}_{3}$ and/or $\mathrm{MgAl}_{2} \mathrm{O}_{4}$ as reported in [16].

The $\mathrm{Mg} 2 \mathrm{p} \mathrm{BE}$ of $50.41 \pm 0 . \mathrm{eV}$ for the grown oxide scale in Figure 10(b) complies well with the corresponding $\mathrm{BE}$ value of $50.4 \pm 0.3 \mathrm{eV}$ for bulk and thin film of $\mathrm{MgAl}_{2} \mathrm{O}_{4}$ [17]. The second species of $\mathrm{Mg} 2 \mathrm{p} \mathrm{BE}$ of $52.17 \pm 0 . \mathrm{eV}$ was confirmed to the compound of $\mathrm{MgO}$. It is slightly higher than the corresponding $\mathrm{Mg} 2 \mathrm{p} \mathrm{BE}$ of $50.8 \pm 0.3 \mathrm{eV}$ as reported for bulk and thin film of $\mathrm{MgO}$ [18]. Figure 10(c) shows an XPS spectrum in the Si 2 p energy region for an oxidized fused metal sample. It is observed that there were two Si species observed using the peak convolution method. The Si peaks deconvoluted at $100.28 \pm 0.1 \mathrm{eV}$ and $103.6 \pm 0.1 \mathrm{eV}$ were expressed as $S i 1$ and $S i$, respectively. The $S i 2$ p peak which is assigned as $\mathrm{Si} 1$ with the $\mathrm{BE}$ of $100.2 \pm 0.1 \mathrm{eV}$ was considered to be due to the formation of Si n-type and the Si 2 peak with a different binding energy of $103.6 \pm 0.1 \mathrm{eV}$ was found to be due to $\mathrm{SiO}_{2}$. In Figure 10(c), the phase separation of oxide states of $\mathrm{Si} 2 \mathrm{p}$ is taking place. At higher temperature, possible formation mechanism involves the exchange of oxygen and $\mathrm{Si}$ leading to the formation of $\mathrm{SiO}_{2}$.

3.4. Thermodynamics of Oxidation. According to the thermodynamics considerations, the Gibbs free-energy change for the formation of a compound, $\Delta G$, is commonly represented as

$$
\Delta G=\Delta H-T \Delta S,
$$

where $\Delta H$ is the enthalpy change and $\Delta S$ is the entropy change in a system.

The calculated values, $\Delta G$, of possible phases that formed after oxidation at temperatures of $600^{\circ} \mathrm{C}$ for 40 hours are listed in Table 3. The $\Delta G_{600}^{\circ}$ for the formation of $\mathrm{MgO}$ at $600^{\circ} \mathrm{C}$ using $1 \mathrm{~mol}$ of $\mathrm{O}_{2}$ was equal to $-1,015.68 \mathrm{~kJ}$ which is lower 


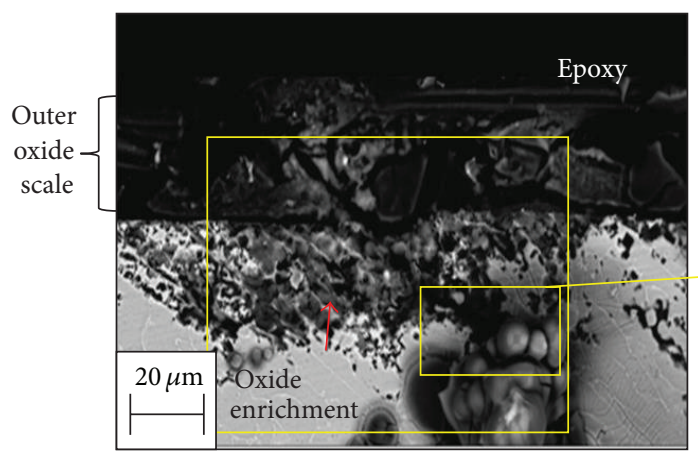

(a)

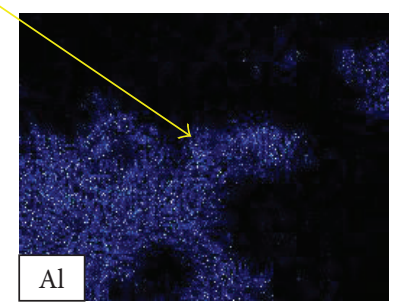

(c)

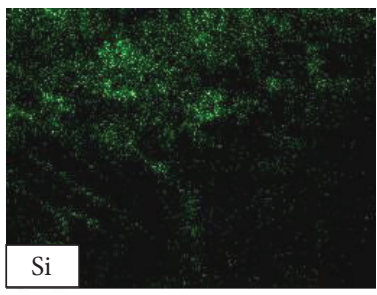

(e)

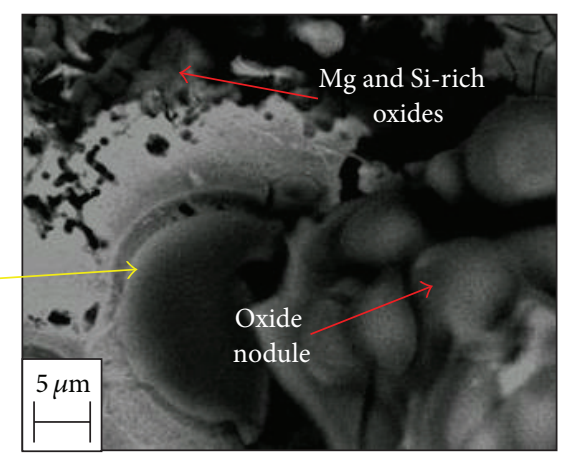

(b)

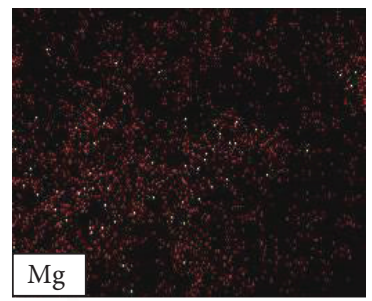

(d)

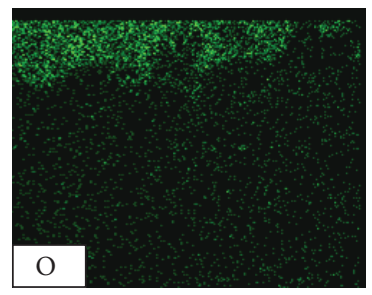

(f)

FIGURE 7: A cross-sectional image of fused metal part of welded AA6061 Al alloy oxidized at $600^{\circ} \mathrm{C}$ for 40 hours, (a) SEM image and (b) expanded SEM image in (a) and EDS maps analyses of (c) Al, (d) Mg, (e) Si, and (f) O.

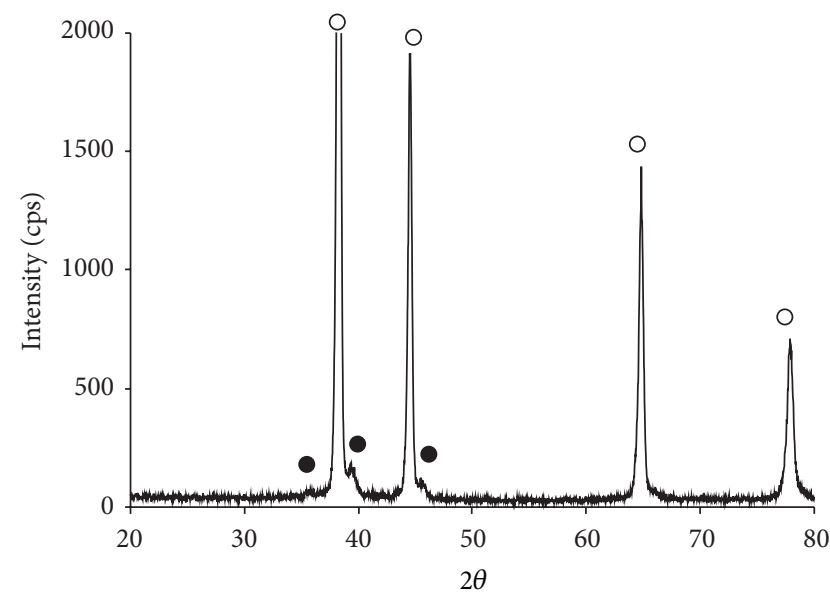

$\circ \mathrm{Al}$

- $\delta-\mathrm{Al}_{2} \mathrm{O}_{3}$

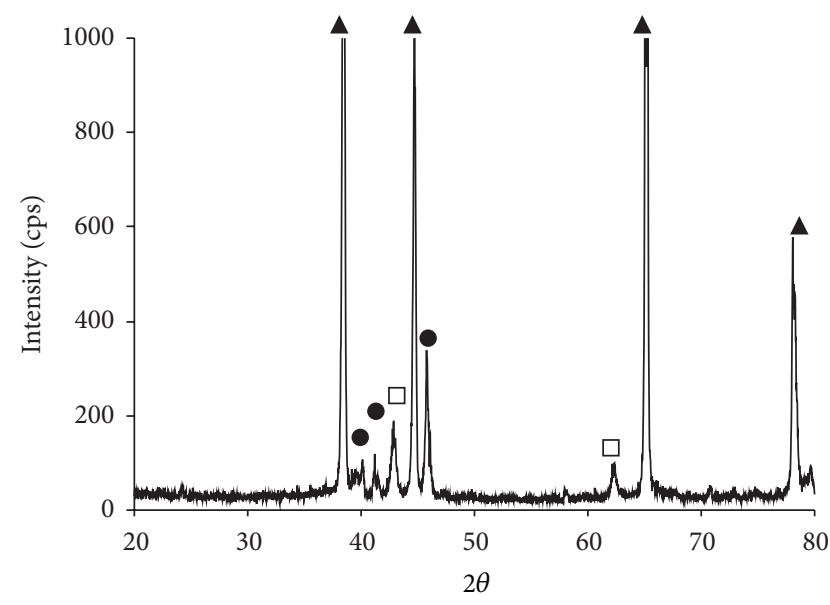

- $\gamma-\mathrm{Al}_{2} \mathrm{O}_{3}$

- $\delta-\mathrm{Al}_{2} \mathrm{O}_{3}$

(a)

(b)

FIGURE 8: XRD diffractograms of fused metal surface of welded AA6061 Al alloy, (a) before and (b) after being subjected to oxidation test for 40 hours at temperature of $600^{\circ} \mathrm{C}$. 
TABLE 3: The possible chemical reaction and standard Gibbs free energies during oxidation at $600^{\circ} \mathrm{C}$.

\begin{tabular}{lccc}
\hline Reaction & $-\Delta H(\mathrm{~J} / \mathrm{g} \cdot \mathrm{mole})$ & $-\Delta S\left(\mathrm{~J} / \mathrm{g} \cdot \mathrm{mole} \cdot{ }^{\circ} \mathrm{K}\right)$ & $\Delta G_{600}^{\circ}(\mathrm{kJ})$ \\
\hline $2 \mathrm{Mg}+\mathrm{O}_{2}(\mathrm{~g}) \rightarrow 2 \mathrm{MgO}$ & $1,219,140$ & 233.04 & $-1,015.68$ \\
$(0.5) \mathrm{Mg}+\mathrm{Al}+\mathrm{O}_{2}(\mathrm{~g}) \rightarrow(0.5) \mathrm{MgAl}_{2} \mathrm{O}_{4}$ & $1,164,035$ & 218.84 & -972.98 \\
$4 / 3 \mathrm{Al}+\mathrm{O}_{2}(\mathrm{~g}) \rightarrow 2 / 3 \mathrm{Al}_{2} \mathrm{O}_{3}$ & $1,121,922$ & 215.47 & -931.66 \\
$2 \mathrm{Mg}+\mathrm{Si} \rightarrow \mathrm{Mg}_{2} \mathrm{Si}$ & 155,600 & -75.0 & -90.12 \\
\hline
\end{tabular}

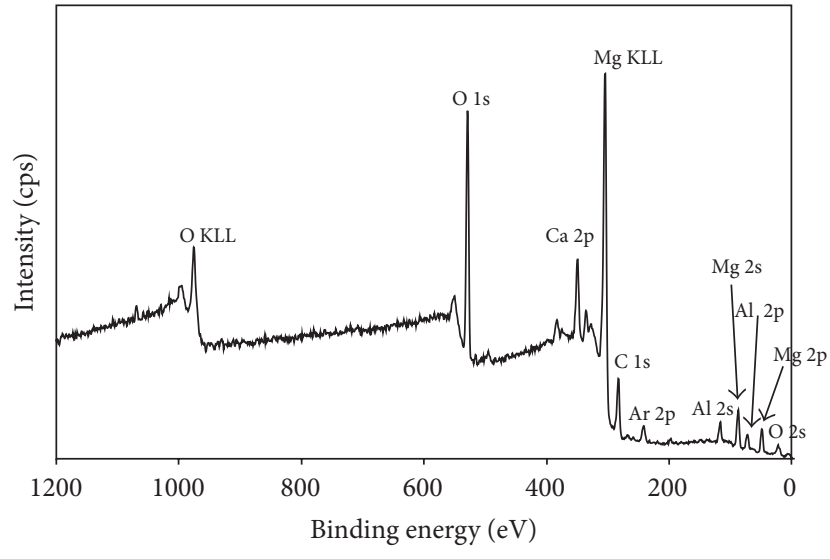

FIGURE 9: The wide XPS spectra of oxidized fused metal surface of AA6061 welded $\mathrm{Al}$ alloy at $600^{\circ} \mathrm{C}$ for 40 hours exposure duration.

than those for $\mathrm{MgAl}_{2} \mathrm{O}_{4}(-972.98 \mathrm{~kJ})$ and $\mathrm{Al}_{2} \mathrm{O}_{3}(-931.66 \mathrm{~kJ})$. Therefore, it is suggested that the order of priority of the reactions is as follows: (1) $\mathrm{Mg}$ was oxidized to $\mathrm{MgO}$, (2) $\mathrm{Mg}$ and $\mathrm{Al}$ were oxidized to $\mathrm{MgAl}_{2} \mathrm{O}_{4}$, and (3) $\mathrm{Al}$ was oxidized to $\mathrm{Al}_{2} \mathrm{O}_{3}$.

Earlier, the presence of $\delta-\mathrm{Al}_{2} \mathrm{O}_{3}$ and $\delta-\mathrm{Al}_{2} \mathrm{O}_{3}$ via XRD, $\mathrm{EDS}$, and XPS was confirmed. Initially, a thin $\mathrm{Al}_{2} \mathrm{O}_{3}$ layer was formed on the surface of the fused metal at room temperature and at the beginning of heating which naturally prevents the alloy surface from corrosion reaction. $\mathrm{Al}_{2} \mathrm{O}_{3}$ is a protective layer which is initially impermeable to water vapour or gases [17-19]. Further heating may lead oxygen to diffuse into the oxide and reach the surface of fused metals.

Then, a new oxidation process started to take place on the oxide-alloy interface to form a new oxide, separating the previously formed oxide from the alloy. Equations (4) to (8) are an example of the possible reactions that may happen during oxidation reactions:

$$
\begin{gathered}
2 \mathrm{Mg}+\mathrm{O}_{2} \longrightarrow 2 \mathrm{MgO} \\
4 \mathrm{Al}+3 \mathrm{O}_{2} \longrightarrow 2 \mathrm{Al}_{2} \mathrm{O}_{3}
\end{gathered}
$$

The above oxidation reactions are exothermic $(\Delta H<0)$ as shown in Table 3. The oxide formed leads the samples to experience weight gain. The oxides then formed $\mathrm{MgAl}_{2} \mathrm{O}_{4}$ through a solid state reaction according to (6) [18-22]. This process involves interdiffusion of $\mathrm{Al}^{3+}$ and $\mathrm{Mg}^{2+}$ ions into $\mathrm{MgO}$ and $\mathrm{Al}_{2} \mathrm{O}_{3}$. It is reported that $\mathrm{MgAl}_{2} \mathrm{O}_{4}$ is hard and porous $[23,24] . \mathrm{MgAl}_{2} \mathrm{O}_{4}$ may also nucleate and grow on the alloy-oxide interface via a direct reaction of $\mathrm{Al}$ and $\mathrm{Mg}$ with $\mathrm{O}_{2}$ as shown by the following [25]:

$$
\mathrm{MgO}+\mathrm{Al}_{2} \mathrm{O}_{3} \longrightarrow \mathrm{MgAl}_{2} \mathrm{O}_{4}
$$

or

$$
\mathrm{Mg}+2 \mathrm{Al}+2 \mathrm{O}_{2} \longrightarrow \mathrm{MgAl}_{2} \mathrm{O}_{4}
$$

It is suggested that the influence of $\mathrm{Mg}$ as an alloying element from the addition of filler metal on the oxidation resistance is mainly to lower the defect associated in the $\mathrm{Al}_{2} \mathrm{O}_{3}$ layer as discussed by Nylund et al. [12]. It has been shown that small amounts of $\mathrm{Mg}$ added to $\mathrm{Al}$ will decrease the oxidation rate. On the other hand, contradicting results were observed when it involved a welded structure that previously experienced solidification process during welding. Moreover, the oxide layer that formed on $\mathrm{Al}$ below $400^{\circ} \mathrm{C}$ is amorphous and it is clearly investigated that the growth of the amorphous oxide follows an inverse logarithmic rate law $[18,20,23]$. In Cabrera and Mott theory, thin films grow at low temperatures predominantly by cation migration and influenced by potential accumulation across the growing film. At an initial stage, the alloy and oxygen reaction mechanism involves the adsorption of gas on the alloy surface [26].

It can be explained that the details of the formation of $\mathrm{MgAl}_{2} \mathrm{O}_{4}$ occur either by the reaction between $\mathrm{Al}_{2} \mathrm{O}_{3}$ layers grown with $\mathrm{Mg}$ in the alloy or by solid state reaction between $\mathrm{MgO}$ phases which grows out of an alloy with internal $\mathrm{Al}_{2} \mathrm{O}_{3}$ layer. This is in line with those reported by Shimizu et al. [20]. Both phases, namely, $\mathrm{MgAl}_{2} \mathrm{O}_{4}$ and $\mathrm{MgO}$, are metastable. Overall, this shows that during the reaction, Mg-rich oxide is formed. During the process of oxide scale growth, the rapid reaction occurs in which the $\mathrm{MgO}$ moves out towards the oxide-gas interface. At the bottom layer a form of $\mathrm{MgAl}_{2} \mathrm{O}_{4}$ from the reaction of $\mathrm{Mg}-\mathrm{Al}-\mathrm{O}$ or $\mathrm{MgO}$ and $\mathrm{Al}_{2} \mathrm{O}_{3}$ layer thickening with increasing temperature. Since the $\mathrm{Mg}$ depleted, it is believed that the low compound of $\mathrm{MgO}$ was formed since $\mathrm{Mg}$ is prone to precipitate with $\mathrm{Si}$ according to the following:

$$
\mathrm{Mg}(\mathrm{s})+2 \mathrm{Si}(\mathrm{s}) \longrightarrow \mathrm{MgSi}_{2}(\mathrm{~s})
$$

With further oxidation, the movement of cation spread to the oxide-gas interface causes $\mathrm{Al}_{2} \mathrm{O}_{3}$ grows towards the surface. At one time, the growth of $\mathrm{Al}_{2} \mathrm{O}_{3}$ is depleted, thus slowing down the oxide growth. At this point $\mathrm{Al}$ is reduced, and further oxidation of $\mathrm{Al}_{2} \mathrm{O}_{3}$ could not continue [12, 27]. In this case, the growth of the nonprotective $\mathrm{MgAl}_{2} \mathrm{O}_{4} / \mathrm{MgO}$ and precipitation of $\mathrm{Mg}$ and $\mathrm{Si}$ on the fused metal surface is significantly pronounced. 


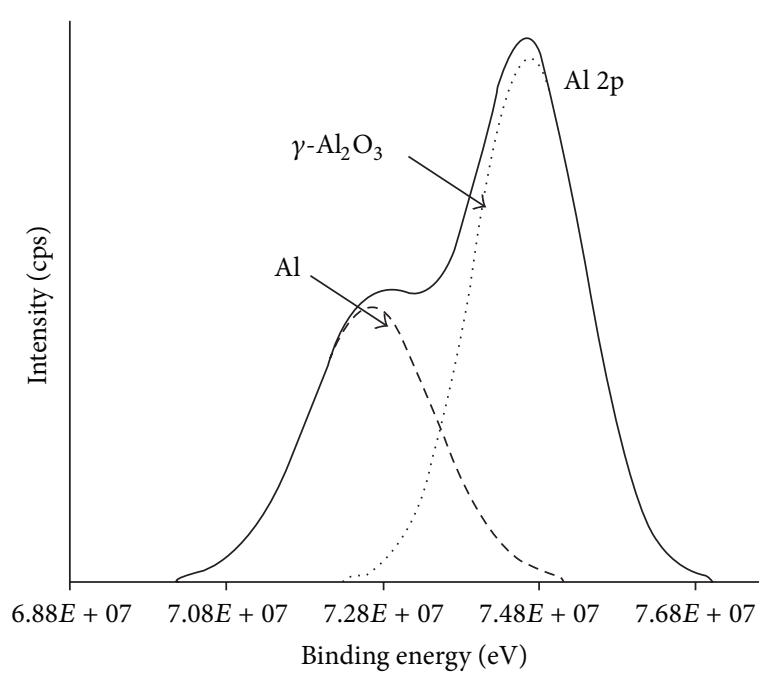

(a)

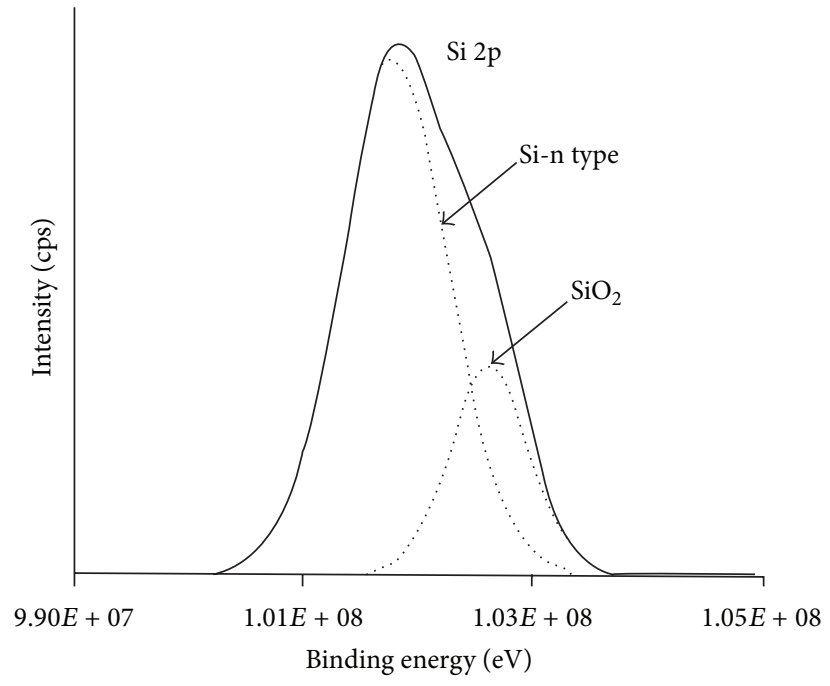

(c)

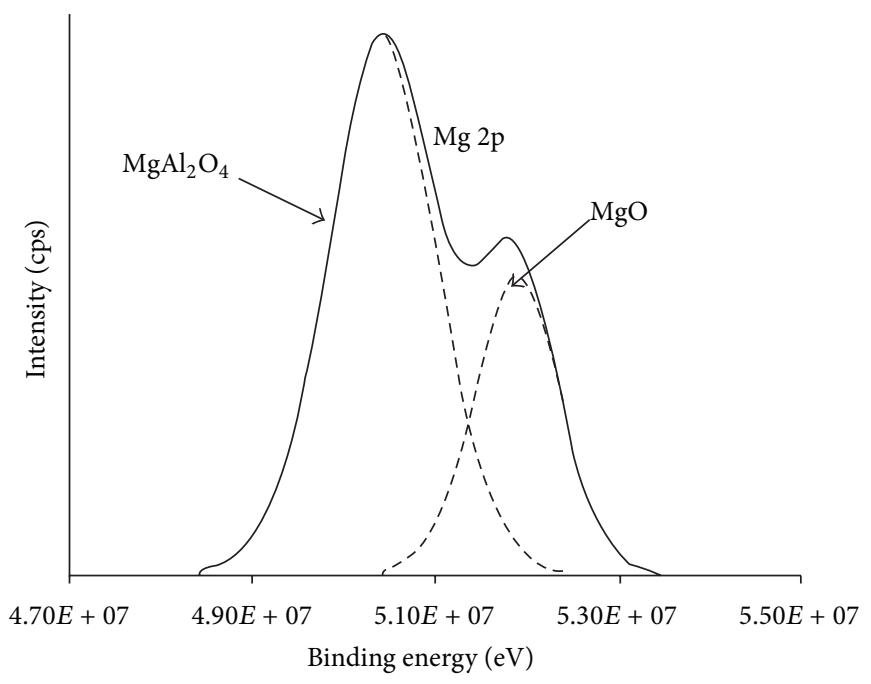

(b)

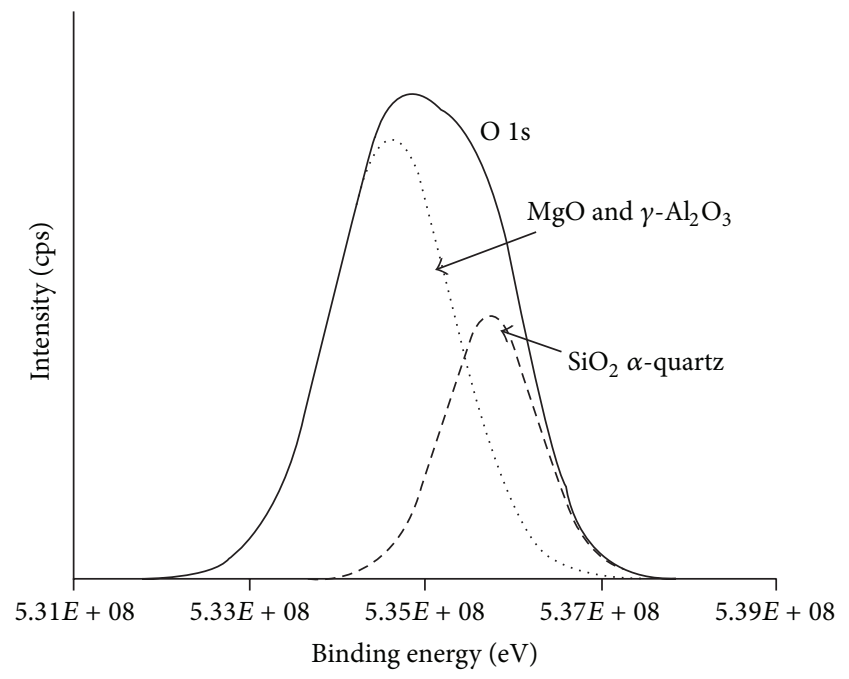

(d)

Figure 10: The detail profile of XPS scan (a) Al 2 p, (b) Mg 2 p, (c) Si 2 p, and (d) O 1 s signals of oxidized fused metal part of AA6061 welded $\mathrm{Al}$ alloy at $600^{\circ} \mathrm{C}$ for 40 hours exposure duration.

Particularly, the unique zone between fused and nonfused base metal which known as fusion boundary were found to be the critical and complex parts where all element compositions lying within the fusion boundary were a mixture of filler and base metal alloys. Pure metals and alloys are not stable especially when it has been exposed to a high temperature oxidation environment [28, 29]. In the case of welded part, a combination of high temperature and oxidation environment with contaminants resulting from previous welding procedure might lead to the internal degradation at a very rapid rate $[30,31]$. Porosity defect in fused metal part also increased the penetration of oxygen which in turn acts as a channel that accelerates the oxidation process. Defects resulting from the welding process and during sample preparation were found to play an important role in assisting the oxidation process. Porosity and voids could increase the rate of oxygen entry into the welded alloy surface and therefore would act as a quick channel or a short pathway for oxidation took place.

According to Arranz and Palacio [28], there is a controversy on the mechanisms of oxygen chemisorptions and nucleation and growth of the surface oxide on single-crystal Al surfaces. They showed that the interaction of oxygen with $\mathrm{Al}$ works in two different ways, either the formation of surface and subsurface species during oxygen adsorption or the simultaneous formation of two-layer oxygen islands and single-layer oxygen islands. The dynamic changes of the chemical state in high temperature oxidation revealed that the $\mathrm{Al}$ substrate containing $\mathrm{Mg}$ will cause the $\mathrm{Mg}$ to be distributed in the matrix and move to the surface. Thus, this process will lead to the concentration of $\mathrm{Mg}$ and reduce the aluminum oxide. It is in agreement with Kimura et al. [29] showing that the result indicates that the appearance of the metallic state was due to the growth of alumina crystallites between the 
surface oxide layer and inner metallic region. It shows that only $\mathrm{Mg}$ concentrated in the oxide layer can reduce the $\mathrm{Al}_{2} \mathrm{O}_{3}$. Consequently, the main oxide entrapped in welded $\mathrm{Al}$ alloy is $\mathrm{MgO}$. It was found to be in agreement with Chen and Wei [30] that the main phases of the oxide films are $\mathrm{MgO}$ and $\mathrm{MgAl}_{2} \mathrm{O}_{4} \cdot \mathrm{MgAl}_{2} \mathrm{O}_{4}$ was recorded to have a low free energy so that it is often formed at the interface of the $\mathrm{Al}$ matrix and $\mathrm{MgO}$. Thus, the mechanism involved is basically based on the diffusion of a solute $\mathrm{Al}$ to the interface to react with oxygen and $\mathrm{MgO}$. It was noted that $\mathrm{MgAl}_{2} \mathrm{O}_{4}$ is more brittle than $\mathrm{MgO}$. The oxides that are entrapped in welded $\mathrm{Al}$ alloy show that it is rich in $\mathrm{Al}, \mathrm{Mg}$, and $\mathrm{O}$. The oxide can serve as a stress raiser where nucleation site takes place. This oxide surface will thus act as a nucleation site for the formation of pores or inclusions in welded $\mathrm{Al}$ alloy.

According to Do et al. [31], it is evident that the addition of $\mathrm{Si}$ or $\mathrm{Mg}$ in $\mathrm{Al}$ bare material will result in an increase or reduction in the number of defects in the oxide scale and therefore lead to the changes in oxidation kinetics. They proved the change of $\mathrm{Mg}$ activity in the $\mathrm{Al}_{2} \mathrm{O}_{3}$ related to the formation of new phase which is a nucleation of a $\mathrm{MgAl}_{2} \mathrm{O}_{4}$. From this investigation, there is a large volume change associated with the transformation from $\mathrm{MgO}$ to $\mathrm{MgAl}_{2} \mathrm{O}_{4}$ [31]. The formation of rapidly growing breakawaytype, $\mathrm{MgAl}_{2} \mathrm{O}_{4}$-rich oxides, comes from the fact that $\mathrm{Mg}$ oxidized internally rather than forming a protective external scale. The mechanism is expected to be promoted by the direct reaction of air gas with alloy surface through a porous surface that contained voids and pores.

\section{Conclusion}

The oxide formed on the fused metal part of AA6061 Al alloy which was joined by gas metal arc welding using an addition of Al-5Mg filler metal; ER5356 was grayish black in color and degrade faster when subjected to high temperature oxidation at $600^{\circ} \mathrm{C}$ for 40 hours. The oxide growth rates based on weight gain at $600^{\circ} \mathrm{C}$ have followed exponential functions. At $600^{\circ} \mathrm{C}$, the oxidation process induces segregation of $\mathrm{Mg}$ from the alloy's interior to the alloy-oxide interface. These segregated $\mathrm{Mg}$ cations incorporated into the oxide which gives rise to the occurrence of $\mathrm{MgO}$ as confirmed by XRD, EDS, and XPS. As long as the grown oxide continued to thicken, $\mathrm{Mg}$ interfacial segregation became larger at $600^{\circ} \mathrm{C}$. The oxidation mechanism AA6061 Al alloy welded joint represents a complex process involving several exothermic reactions which produced $\delta-\mathrm{Al}_{2} \mathrm{O}_{3}, \gamma-\mathrm{Al}_{2} \mathrm{O}_{3}, \mathrm{MgO}$, and $\mathrm{MgAl}_{2} \mathrm{O}_{4}$. In addition, XPS results have been found to be consistent with the interpretation of the existence of oxide phases which grow and cover the surface completely.

\section{Conflict of Interests}

The authors declare that there is no conflict of interests regarding the publication of this paper.

\section{Acknowledgments}

The authors would like to thank the Ministry of Higher Education Malaysia and Universiti Kebangsaan Malaysia (UKM) for supporting this work through research Grants FRGS/1/2011/ST/UKM/02/14, UKM-GGPM-NBT-089-2010, DIP-2012-14, DPP-2013-035, and STRG1033. One of the authors, Nur Azida Che Lah, would like to thank Universiti Kuala Lumpur Malaysia France Institute (Unikl MFI) and Majlis Amanah Rakyat (MARA) for granting a fellowship for her doctoral study. The authors kindly declare that "Submission of the article implies that the work describe has not been published elsewhere."

\section{References}

[1] D. T. L. van Agterveld, G. Palasantzas, and J. Th. M. De Hosson, "Magnesium surface segregation and oxidation in Al-Mg alloys studied with local probe scanning Auger-scanning electron microscopy," Applied Surface Science, vol. 152, no. 3, pp. 250 258, 1999.

[2] F. Andreatta, H. Terryn, and J. H. W. De Wit, "Corrosion behaviour of different tempers of AA7075 aluminium alloy," Electrochimica Acta, vol. 49, no. 17-18, pp. 2851-2862, 2004.

[3] E. Arslan, Y. Totik, E. E. Demirci, Y. Vangolu, A. Alsaran, and I. Efeoglu, "High temperature wear behavior of aluminum oxide layers produced by AC micro arc oxidation," Surface and Coatings Technology, vol. 204, no. 6-7, pp. 829-833, 2009.

[4] S. Maggiolino and C. Schmid, "Corrosion resistance in FSW and in MIG welding techniques of AA6XXX," Journal of Materials Processing Technology, vol. 197, no. 1-3, pp. 237-240, 2008.

[5] A. F. Beck, M. A. Heine, E. J. Caule, and M. J. Pryor, “The kinetics of the oxidation of $\mathrm{Al}$ in oxygen at high temperature," Corrosion Science, vol. 7, no. 1, pp. 1-22, 1967.

[6] G. C. Wood and F. H. Stott, "Oxidation of alloys," Materials Science and Technology, vol. 3, no. 7, pp. 519-530, 1986.

[7] M. F. Frolish, M. Krzyzanowski, W. M. Rainforth, and J. H. Beynon, "Oxide scale behaviour on aluminium and steel under hot working conditions," Journal of Materials Processing Technology, vol. 177, no. 1-3, pp. 36-40, 2006.

[8] F. Reichel, L. P. H. Jeurgens, and E. J. Mittemeijer, "The effect of substrate orientation on the kinetics of ultra-thin oxide-film growth on Al single crystals," Acta Materialia, vol. 56, no. 12, pp. 2897-2907, 2008.

[9] U. K. Mudali and B. Raj, Corrosion Science and Technology, Alpha Science International, 2008.

[10] F. Czerwinski, "The oxidation behaviour of an AZ91D magnesium alloy at high temperatures," Acta Materialia, vol. 50, no. 10, pp. 2639-2654, 2002.

[11] V. V. Doilnitsyna, "General diffusion-kinetic model of metallic oxidation," Corrosion Science, vol. 44, no. 5, pp. 1113-1131, 2002.

[12] A. Nylund, K. Mizuno, and I. Olefjord, "Influence of Mg and Si on the oxidation of aluminum," Oxidation of Metals, vol. 50, no. 3-4, pp. 309-325, 1998.

[13] L. P. H. Jeurgens, M. S. Vinodh, and E. J. Mittemeijer, "Initial oxide-film growth on $\mathrm{Mg}$-based $\mathrm{MgAl}$ alloys at room temperature," Acta Materialia, vol. 56, no. 17, pp. 4621-4634, 2008.

[14] C.-S. Yang, J.-S. Kim, J.-W. Choi et al., "XPS study of aluminum oxides deposited on PET thin film," Journal of Industrial and Engineering Chemistry, vol. 6, no. 3, pp. 149-156, 2000. 
[15] J. F. Moulder, W. F. Stickle, P. E. Sobol, and K. D. Bomben, HandBook of X-Ray Photoelectron Spectroscopy, A Reference Book of Standard Spectra For Identification and Interpretation of XPS Data, Perkin-Elmer Corporation, Waltham Mass, USA, 1992.

[16] M. Frerichs, F. Voigts, and W. Maus-Friedrichs, "Fundamental processes of aluminium corrosion studied under ultra high vacuum conditions," Applied Surface Science, vol. 253, no. 2, pp. 950-958, 2006.

[17] J. A. S. Tenório and D. C. R. Espinosa, "High-temperature oxidation of Al-Mg alloys," Oxidation of Metals, vol. 53, no. 3, pp. 361-373, 2000.

[18] H. Venugopalan, K. Tankala, and T. DebRoy, "Kinetics of directed oxidation of Al-Mg alloys in the initial and final stages of synthesis of $\mathrm{Al}_{2} \mathrm{O}_{3} / \mathrm{Al}$ composites," Materials Science and Engineering A, vol. 210, no. 1-2, pp. 64-75, 1996.

[19] N. Arivazhagan, S. Singh, S. Prakash, and G. M. Reddy, "High temperature corrosion studies on friction-welded dissimilar metals," Materials Science and Engineering B, vol. 132, no. 1-2, pp. 222-227, 2006.

[20] K. Shimizu, G. M. Brown, K. Kobayashi, P. Skeldon, G. E. Thompson, and G. C. Wood, "The early stages of high temperature oxidation of an Al-0.5 wt\% Mg alloy," Corrosion Science, vol. 40, no. 4-5, pp. 557-575, 1998.

[21] N. K. Othman, N. Othman, J. Zhang, and D. J. Young, "Effects of water vapour on isothermal oxidation of chromia-forming alloys in $\mathrm{Ar} / \mathrm{O}_{2}$ and $\mathrm{Ar} / \mathrm{H}_{2}$ atmospheres," Corrosion Science, vol. 51, no. 12, pp. 3039-3049, 2009.

[22] N. K. Othman, A. Jalar, N. Othman, and D. J. Young, "Effects of lanthanum on Fe-25Cr alloys under cyclic oxidation," Advanced Materials Research, vol. 97-101, pp. 1212-1215, 2010.

[23] V. Y. Chekhovskoi and V. D. Tarasov, "A procedure for rapid studies of the metal oxidation kinetics at high temperatures," Instruments and Experimental Techniques, vol. 51, no. 3, pp. 476479, 2008.

[24] S. Chevalier, C. Nivot, and J. P. Larpin, "Influence of reactive element oxide coatings on the high temperature oxidation behavior of alumina-forming alloys," Oxidation of Metals, vol. 61, no. 3-4, pp. 195-217, 2004.

[25] E. Bergsmark, C. J. Simensen, and P. Kofstad, "Oxidation of molten aluminium," Materials Science and Engineering A, vol. A120-1, no. 1, pp. 91-95, 1989.

[26] H. Jafari, M. H. Idris, and A. Ourdjini, "High temperature oxidation of AZ91D magnesium alloy granule during in-situ melting," Corrosion Science, vol. 53, no. 2, pp. 655-663, 2011.

[27] P. Kofstad, High Temperature Corrosion, Elsevier, London, UK, 1988.

[28] A. Arranz and C. Palacio, "Characterization of the surface and interface species formed during the oxidation of aluminum," Surface Science, vol. 355, no. 1-3, pp. 203-213, 1996.

[29] A. Kimura, M. Shibata, K. Kondoh et al., "Reduction mechanism of surface oxide in aluminum alloy powders containing magnesium studied by x-ray photoelectron spectroscopy using synchrotron radiation," Applied Physics Letters, vol. 70, no. 26, pp. 3615-3617, 1997.

[30] Y.-J. Chen and P.-S. Wei, "Diagnosis and analysis of oxide films in cast magnesium alloys by ultrasonic-vibration treatment," Materials Transactions, vol. 48, no. 12, pp. 3181-3189, 2007.

[31] T. Do, S. J. Splinter, C. Chen, and N. S. McIntyre, “The oxidation kinetics of Mg and Al surfaces studied by AES and XPS," Surface Science, vol. 387, no. 1-3, pp. 192-198, 1997. 

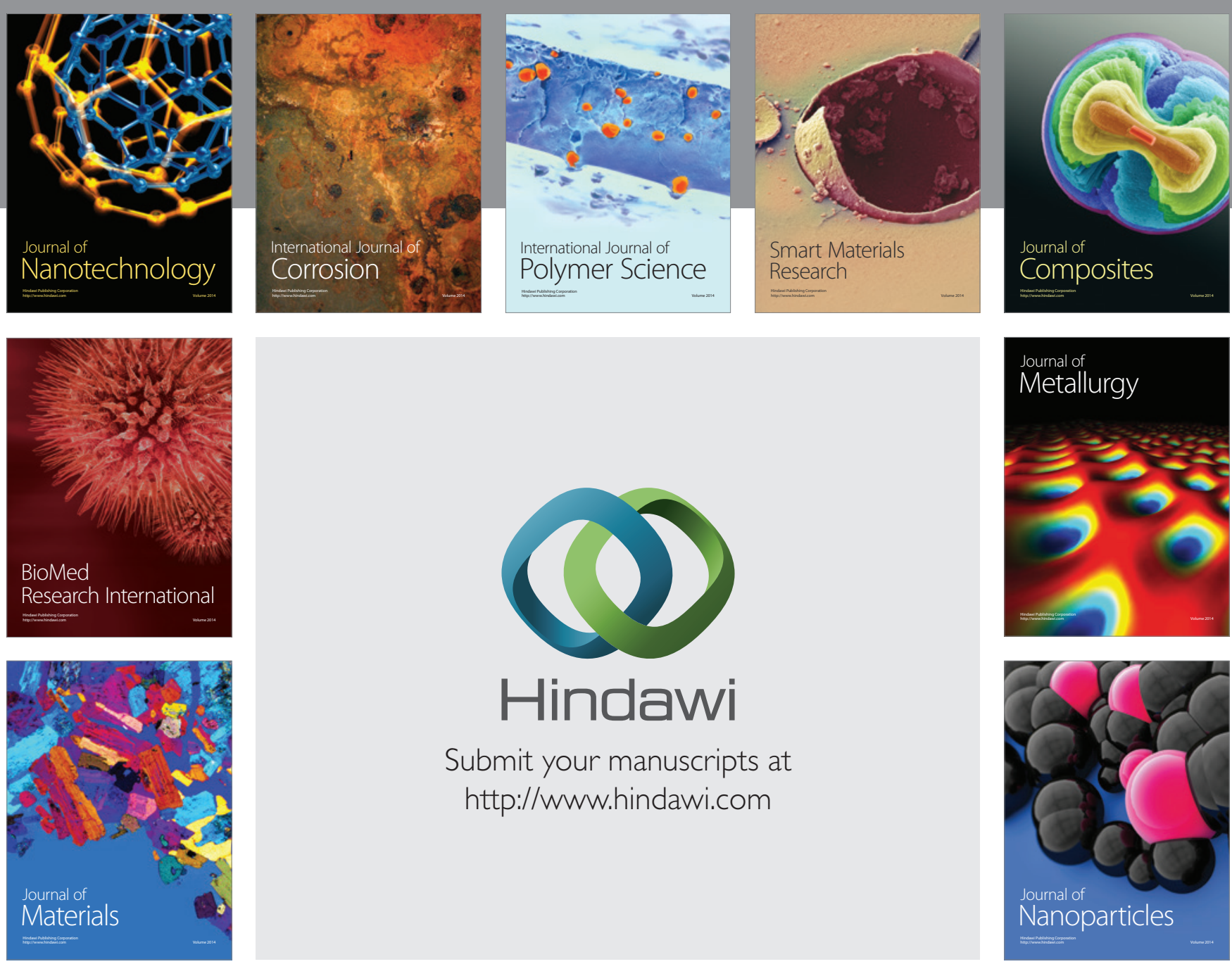

Submit your manuscripts at http://www.hindawi.com
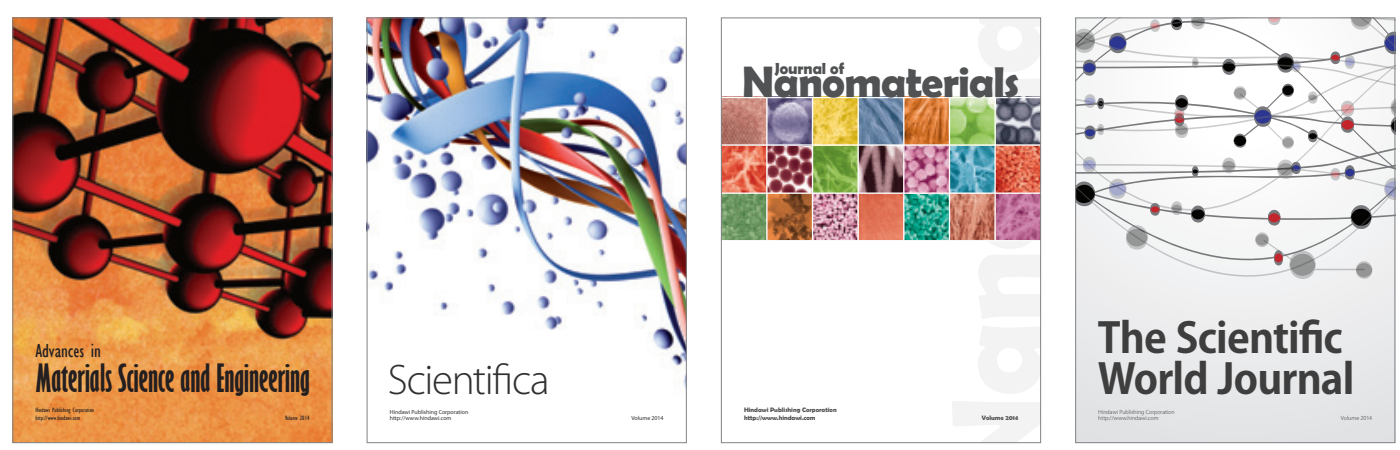

\section{The Scientific World Journal}
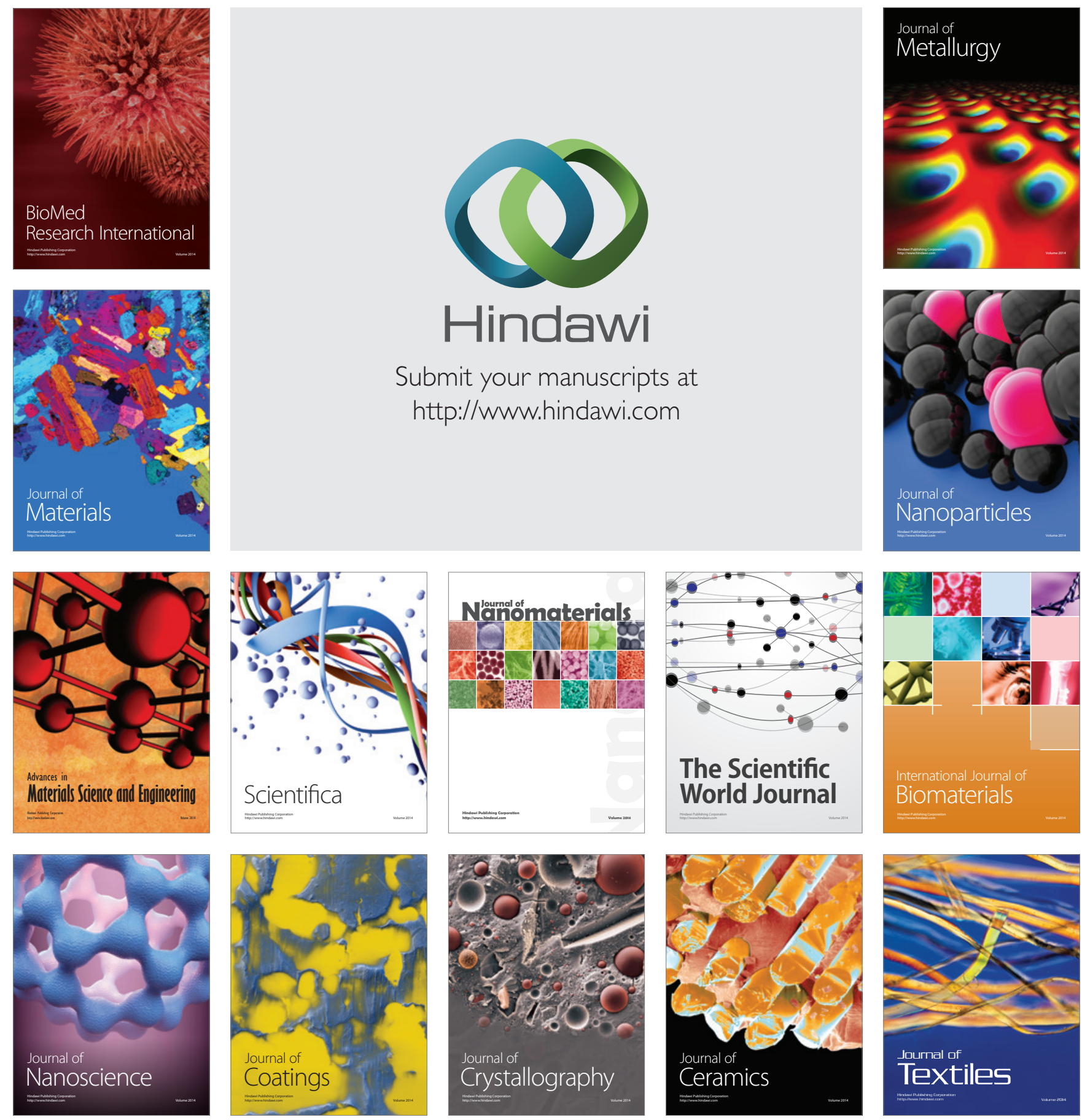